\title{
Development of A Peer Assessment Scientific Attitude Assessment Instrument on Learning Short Story Texts of Class XI Students at State Senior High School 1 Kualuh Hilir
}

\author{
Hanifah Sitorus Pane ${ }^{1}$, Syahnan Daulay ${ }^{2}$, M. Oky Fardian Gafari ${ }^{2}$ \\ ${ }^{I}$ Master Student in State University of Medan (UNIMED), Medan, Indonesia \\ ${ }^{2}$ Lecturer in State University of Medan (UNIMED), Medan, Indonesia \\ hanifahpane@yahoo.com
}

\begin{abstract}
Peer assessment is a form of assessment of a student towards other students. In peer assessment, students are involved directly in the assessment process. The aim is to develop of a peer assessment scientific attitude assessment instrument on learning short story text of XI students at State Senior High School 1 Kualuh Hilir. Methodology of this research uses quantitative and to find the results of the development research presented in this discussion are, describing the process of developing a scientific assessment instrument based on peer assessment, describing the feasibility of peer assessment based scientific attitude assessment instruments, describing the results of testing instruments for evaluating students' scientific attitudes based on peer assessment in short story text learning.
\end{abstract}

Keywords : assessment; scientific attitude; short story

\section{Introduction}

Peer assessment is a form of assessment of a student towards other students. In peer assessment, students are involved directly in the assessment process. In the application of peer assessment, it is expected that students can build criticism and input directly to the students assessed, because usually if the assessment is only limited to the teacher, it is constrained by the number of students who many teachers find it difficult to criticize errors and assess student attitudes one by one. The results of the Amhag study (2013) revealed that peer assessment (peer learning) can support students' creative and critical abilities, and provide opportunities for cognitive meta learning. Research conducted by Thomas, Dona, and Kathleen (2011) states that future learning-oriented assessments involve students in the assessment process to improve short-term and long-term outcomes by asking students to make judgments about their peers.

Peer assessment is also a form of assessment made by a student towards other students. (Center for Educational Development, 2002) Evaluation of peers separately has the advantage that students get learning and knowledge from the performance results of their peers, so as to minimize errors in the learning process. This can be feedback for students to improve the quality of their learning. In addition, assessment of peer evaluations can also train students to be honest, objective, and have a sense of responsibility. According to Larisey in Karsidi, et al. (2013: 22) students in adult conditions need to be given the opportunity to learn directly, be critical and be given the opportunity to be involved in the assessment. Assessment carried out by students is called self or peer assessment, while peer assessment according to Falchikov in Spiller (2012: 10) is to ask students to give one feedback or assessment (or both) to a friend on a product or performance, which is based on good criteria for products or events that enable student involvement in assessment.

The application of peer assessment can be a learning tool for students to assess by comparing it with the assessment criteria, and developing the values of scientific attitudes in students, such as cooperation, curiosity, honesty in assessing, openness in giving judgment means students can be objective. Students' critical attitudes can also be trained when students 
are involved in learning activities. If the peer assessment model is applied by the teacher in the classroom, then the student feels that being involved plays a role in the assessment when the learning process takes place.

Teaching Indonesian is directed at improving students' ability to communicate using Indonesian language properly and correctly, both verbally and in writing. In accordance with the objectives of teaching Indonesian language, it is expected that students can develop their potential according to their abilities, needs, and interests. According to Sutawijaya in (Yanti, 2013: 2) Short Story is a story whose essence is one form of art statement that uses language as a medium of communication. In learning Indonesian, especially in class XI, there are five genres of text that must be studied, namely short story texts, pantun story texts, repeated story texts, complex explanatory texts, and text / drama review / review texts. In this study, researchers focused on one of the literary texts namely short story texts.

Short stories are containers that are usually used by authors to present a small part of the life of the person who most attracts the attention of the author. Analyzing and editing short story texts can be used as a means to devote one's ideas and ideas. However, the lack of training and guidance from the teacher made many students confused when making short story texts. The ability to analyze and edit short story texts is needed by students because it can provide a clear picture in making short story texts, and can encourage readers to participate in the practice of analyzing and editing a short story text.

\section{Literature review}

\subsection{Definition of Instruments}

Understanding instruments According to Arikunto (2014: 191) is a tool that is selected and used by researchers in collecting data so that the activity becomes systematic and can be facilitated by it. Sumadi (2008: 52) Definition of instruments in the scope of evaluation is defined as a device for measuring student learning outcomes that includes learning outcomes in the cognitive, affective and psychomotor domains.

The form of the instrument can be in the form of tests and non-tests. The instrument in the form of a test includes a description test (objective description and free description), multiple choice tests, short answers, matchmaking, correctness, performance (performance test), and portfolio. Non-test form instruments include interviews, questionnaires and observations. Before the instrument is used it should be analyzed first. Two important characteristics in analyzing instruments are their validity and reliability. The instrument is said to be valid (correct / valid) if the instrument is used to measure what should be measured. In this case the target to whom the instrument is intended is one aspect that must be considered in analyzing the validity of an instrument. Other aspects include the suitability of indicators with items, language usage, conformity with the applicable curriculum, rules for writing items etc.

\subsection{Assessment Instrument}

The assessment instrument is a tool that can be used to measure or assess the level of competence achievement. In addition, the instrument is also interpreted as a tool that is selected and used in learning activities to collect so that the learning activities become systematic and facilitated by them. According to, Arikunto (2012), assessment instruments are grouped into two types, namely tests and non-tests. 
Based on these definitions an instrument serves to capture learning outcomes. Instruments are also interpreted as aids, are suggestions that can be realized in objects, such as questionnaires (questionnaires), matching lists (check list), interview guidelines (interview guide or interview schedule), test questions (test), inventory (inventory), and scale.

Data collection and measurement is carried out using instruments or measuring instruments. In connection with measurements in the framework of collecting data, if a standard measuring instrument already exists, the measurement can be directly carried out with a measuring instrument that fits the measurement needs. In natural science there are many standard measuring instruments such as meters, scales, thermometers, watches, and so on. In social sciences many experts have standardized measuring instruments for several measurement needs.

According to Purwanto (2021: 7) in social research if you want to use a standard measuring instrument for measurement, data collection needs to report the results of testing the quality of a measuring instrument by the person who has standardized it. In social research, including education, there are not many measuring instruments that have been standardized. Furthermore, Purwanto (2012: 7) in such circumstances, the researcher must first standardize the measuring instrument that will be used for data collection. So the instrument should be tested first for instrument revisions, such as removing unnecessary items, replacing them with new items.

\subsection{Scientific attitude}

Scientific attitude is an attitude that must exist in a scientist or academic when facing scientific problems. This scientific attitude needs to be familiarized in various scientific forums, for example in discussions, seminars, workshops, and scientific writing (Apriani, 2011). A scientific attitude is also an attitude that must exist in a scientist or academic when facing scientific problems.

Burhanuddin (2005: 38) argues that scientific attitude is a person's view of ways of thinking that are in accordance with scientific methods, so that there arises a tendency to accept or reject the way of thinking in accordance with the science. In other words, the tendency of someone does an action or behavior in solving a problem systematically through scientific steps. A scientist must clearly have a positive attitude, or a tendency to accept ways of thinking that are in accordance with scientific methods, which are manifested in their cognition, emotions or feelings and in their behavior.

\subsection{Peer Assessment}

Peer assessment is a process of a student assessing the learning outcomes of friends or other students at the same level. According Ansari, et al (2016: 1-2) Peer assessment encourages students to have a sense of responsibility towards the learning process so that students can be independent, practice evaluating skills that are useful for life long learning, and encourage deep learning (learning that deep). Peer assessment can be used to help students develop the ability to cooperate, criticize the process and results of other people's learning (formative assessment), receive feedback or criticism from others, give students a deep understanding of the criteria used to assess learning processes and outcomes and for summative assessment.

Peer assessment (assessment of peers) is an assessment between students by asking students to assess each other related to the achievement of competence. Peer assessment is also a collaborative member process from a team assessing each other (being an assessor), so 
the characteristics of the peer assessment are appropriate for peer learning. Peer Assessment is stated as an assessment approach that can improve cognitive skills and can measure students' social skills. Conant (1997) indicated, that the peer assessment model (1) emphasizes the use of high-level thinking skills, (2) can develop social skills and (3) create a sense of responsibility and personal empowerment of students. Characteristics of peer assessment, among others, peer assessment is a process for members of a team to assess each other (assessment), the goal setting must be understood by students well. Peer assessment as an alternative assessment gives freedom to students to express opinions. Peer assessments can be grouped with the Reciprocal Teaching and / or Feedback rather than skills that are measured and assessed, can be used for formative assessment and summative assessment. 2.5 Short stories

Short stories or often called short stories are a form of fictional narrative prose. Short stories tend to be dense and directly to their goals compared to longer works of fiction such as novella (in the modern sense) and novels. The definition of short stories is not determined by the number of pages to realize the story or at least the characters contained in the story, according to the scope of the problems to be conveyed by the author in the form of the literary work. So a short story may not necessarily be classified into the type of short story, if the scope and problems expressed do not meet the requirements demanded by the short story also adds that short stories are containers that are usually used by authors to present only a small portion of the life of the most attract the attention of the author.

Cepen is a type of fiction. Short stories have elements of story, plot, background, characters that are narrower than novels. Sumardjo (2007: 202) states that short stories are fictions that are read in one sitting. Therefore, the stories presented in the short stories only have one story or one event. According to Edgar Allan Poe (through Nurgiyantoro, 2007: 10), short stories are stories that are read in one sitting, about half to two hours - a thing that might not be possible for a novel.

Short stories have varying lengths. There is a short short story and the number of words is around 500 words, there are short stories that are quite long (midle short story), and there are long short stories (long short stories), which consist of thousands of words. Meanwhile, Sayuti (2000: 10) states that short stories show compression quality, concentration "concentration", and "deepening" intensity, all of which relate to the length of the story and the structural qualities implied by the length of the story.

Based on the opinions of the experts above, it can be concluded that short stories are short stories that have fewer compositions than novels in terms of story density, focus on one character, one situation and are completely read. Conflicts presented in short stories usually only develop one event so the short story becomes interesting because of the limitations of the object or event that is told.

\section{Research Methodology}

This type of research is development research in the field of education known as Research and Develop (R \& D). According to Borg and Gall (2005), development research is a process used to develop and validate educational products. The development model used in this study is a 4D model that is modified into 3D. The location of this study is in SMA 1 Kualuh Hilir. The implementation of the study was conducted in the Learning Year 2018/2019. The subjects in this study were 32 students of class XI SMA 1 Kualuh Hilir as 
many as 32 students, while the objects in this study were peer assessment based scientific attitude assessment instruments.

\section{Discussion}

The results of this study suggest a discussion of the results of the development of peer assessment based scientific attitude assessment. The results of the development research presented in this discussion are, describing the process of developing a scientific assessment instrument based on peer assessment, describing the feasibility of peer assessment based scientific attitude assessment instruments, describing the results of testing instruments for evaluating students' scientific attitudes based on peer assessment in short story text learning.

The researcher collected information based on observations in Class XI SMA 1 Kualuh Hilir by distributing questionnaires to 3 teachers and several students. The results of the inquiry questionnaire distributed by all teachers stated that the learning process with a scientific assessment instrument based on peer assessment was needed because it had a positive impact, namely utilizing available facilities and infrastructure and motivating students to learn more passionately to obtain better abilities.

Then students also stated that they really need it in the learning process because they can learn independently and can repeat material that has not been mastered until it becomes more understanding. Data on the needs analysis are shown in Table 4.1 below.

Table 4.1 Data Analysis of Needs for Scientific Attitude Assessment Instruments

\begin{tabular}{|c|c|c|c|c|c|c|}
\hline \multirow[b]{2}{*}{$\begin{array}{l}\text { No } \\
\text {. }\end{array}$} & \multirow{2}{*}{$\begin{array}{l}\text { The Kinds of } \\
\text { informations }\end{array}$} & \multirow[b]{2}{*}{ Answer } & \multicolumn{3}{|c|}{ Frequency } & \multirow[b]{2}{*}{ Percentage } \\
\hline & & & $\begin{array}{l}\text { Teach } \\
\text { er }\end{array}$ & $\begin{array}{c}\text { Stu } \\
\text { dent }\end{array}$ & total & \\
\hline \multirow[t]{2}{*}{1.} & \multirow{2}{*}{$\begin{array}{l}\text { Know or not an attitude } \\
\text { assessment instrument. }\end{array}$} & Yet & 3 & 0 & 3 & $16,67 \%$ \\
\hline & & No & 0 & 15 & 15 & $83,33 \%$ \\
\hline \multirow[t]{2}{*}{2.} & \multirow{2}{*}{$\begin{array}{l}\text { Use or not an instrument } \\
\text { for evaluating scientific } \\
\text { attitudes to assess peers. }\end{array}$} & Yet & 0 & 0 & 0 & $0 \%$ \\
\hline & & Not yet & 3 & 15 & 18 & $100 \%$ \\
\hline \multirow[t]{2}{*}{3.} & \multirow{2}{*}{$\begin{array}{l}\text { Requires or not a scientific } \\
\text { attitude assessment } \\
\text { instrument to assess peers } \\
\text { in learning short story } \\
\text { texts. }\end{array}$} & Yes & 3 & 15 & 18 & $100 \%$ \\
\hline & & No & 0 & 0 & 0 & $0 \%$ \\
\hline
\end{tabular}

Based on Table 4.1 regarding data needs analysis by teachers and students, it was concluded that all teachers stated that they were familiar with attitude assessment instruments, and all students did not recognize the attitude assessment instruments. Furthermore, it was found that the teacher was familiar with the scientific attitude assessment instrument used by using students to assess their friends.

All teachers also stated that they had not used scientific attitude assessment instruments to assess peers, and all students stated that they had never used scientific attitude assessment instruments to assess peers. It was further found that the teacher had never developed a scientific attitude assessment instrument to assess students' abilities in short story text learning. 
Furthermore, all teachers stated that they needed a scientific attitude assessment instrument to assess peers in learning short story texts, and all students stated that they needed a scientific attitude assessment instrument to assess peers in short story text learning. By using peer-based scientific attitude assessment students can learn independently, more actively and eagerly because the scientific attitude assessment instrument can repeat the material at home or in the workplace in the hope of obtaining better abilities.

Based on the results of the general needs analysis above, it can be concluded that the development of scientific attitude assessment instruments based on peer assessment in the learning process is needed by teachers and students. Therefore the teachers stated that they really needed peer assessment instruments based on scientific attitude in the learning process to analyze short story texts, because so far it was difficult to get an effective scientific attitude assessment instrument to deliver learning material to analyze short story texts.

Table 4.2 Teacher's response Against the Instrument of Scientific Attitude Assessment

\begin{tabular}{|c|l|}
\hline No & \multicolumn{1}{|c|}{ Teacher's response } \\
\hline $\mathbf{1}$ & $\begin{array}{l}\text { The overall appearance of the instrument's assessment of scientific } \\
\text { attitudes is interesting. }\end{array}$ \\
\hline $\mathbf{2}$ & $\begin{array}{l}\text { The language used and the presentation of the material are arranged and } \\
\text { easy to understand }\end{array}$ \\
\hline $\mathbf{3}$ & The use of question instructions in the instrument is clear \\
\hline $\mathbf{4}$ & $\begin{array}{l}\text { The instrument for evaluating scientific attitudes is different from the } \\
\text { usual instruments used. }\end{array}$ \\
\hline $\mathbf{5}$ & $\begin{array}{l}\text { This instrument of scientific attitude assessment is very helpful in the } \\
\text { assessment process. }\end{array}$ \\
\hline
\end{tabular}

Table 4.3 Student Responses Against the Instrument of Scientific Attitude Assessment

\begin{tabular}{|c|l|}
\hline No & \multicolumn{1}{|c|}{ Student's Response } \\
\hline $\mathbf{1}$ & I easily learn and use this instrument. \\
\hline $\mathbf{2}$ & $\begin{array}{l}\text { The presentation of this assessment instrument has been arranged in its } \\
\text { entirety. }\end{array}$ \\
\hline $\mathbf{3}$ & This instrument encourages my curiosity towards colleagues. \\
\hline $\mathbf{4}$ & $\begin{array}{l}\text { This assessment instrument is very helpful for the assessment process, } \\
\text { especially learning short story texts. }\end{array}$ \\
\hline $\mathbf{5}$ & $\begin{array}{l}\text { Using this assessment instrument can make it easier for us to judge } \\
\text { colleagues. }\end{array}$ \\
\hline
\end{tabular}

\subsubsection{Feasibility of Peer Assessment-based Scientific Attitude Assessment Instruments}

Validation is an important part in developing assessment instruments to correct some errors and weaknesses from the product design results that have been made by researchers. The following will describe the results of the validation and revision carried out on peer assessment based scientific attitude assessment instruments.

Material Analysis 
Tabel 4.4 Results of Material Expert Validation

\begin{tabular}{|c|c|c|c|c|c|c|}
\hline \multirow[t]{2}{*}{ No } & \multirow[t]{2}{*}{ Aspect } & \multirow[t]{2}{*}{ Indicator } & \multicolumn{2}{|c|}{$\begin{array}{c}\text { Validato } \\
\mathbf{r}\end{array}$} & \multirow[t]{2}{*}{$\%$} & \multirow[t]{2}{*}{ Criteria } \\
\hline & & & 1 & 2 & & \\
\hline \multirow[t]{6}{*}{ A } & \multirow{6}{*}{$\begin{array}{l}\text { Compatibil } \\
\text { ity of } \\
\text { material } \\
\text { with KI } \\
\text { and KD }\end{array}$} & $\begin{array}{l}\text { 1. Extent of assignment material in } \\
\text { accordance with student } \\
\text { competency based on lesson plan }\end{array}$ & 3 & 3 & $75 \%$ & Very valid \\
\hline & & $\begin{array}{l}\text { 2. Instruments made in accordance } \\
\text { with the learning objectives }\end{array}$ & 4 & 3 & $87,5 \%$ & Very valid \\
\hline & & $\begin{array}{l}\text { 3. The instrument is in accordance } \\
\text { with the material being taught }\end{array}$ & 3 & 4 & $87,5 \%$ & Very valid \\
\hline & & $\begin{array}{l}\text { 4. Instruments are easy to } \\
\text { understand and understand }\end{array}$ & 3 & 4 & $87,5 \%$ & Very valid \\
\hline & & $\begin{array}{l}\text { 5. The assessment instrument can } \\
\text { collect all student assessment } \\
\text { data on the material analyzing } \\
\text { short story text building elements }\end{array}$ & 4 & 4 & $100 \%$ & Very valid \\
\hline & & $\begin{array}{l}\text { 6. Instruments can access scientific } \\
\text { understanding and reasoning. }\end{array}$ & 3 & 4 & $87,5 \%$ & Very valid \\
\hline \multirow[t]{4}{*}{$\mathrm{B}$} & \multirow{4}{*}{$\begin{array}{l}\text { Language } \\
\text { and } \\
\text { instrument } \\
\text { writing }\end{array}$} & $\begin{array}{l}\text { 7. Using language that is in } \\
\text { accordance with PUEBI and easy } \\
\text { to understand }\end{array}$ & 4 & 4 & $100 \%$ & Very valid \\
\hline & & 8. Consistent use of fonts (letters) & 3 & 4 & $87,5 \%$ & Very valid \\
\hline & & $\begin{array}{l}\text { 9. Use the right distance, row and } \\
\text { space }\end{array}$ & 4 & 4 & $100 \%$ & Very valid \\
\hline & & $\begin{array}{l}\text { 10. Use paper format and typing } \\
\text { layout }\end{array}$ & 3 & 3 & $75 \%$ & Very valid \\
\hline \multirow[t]{4}{*}{$\mathrm{C}$} & \multirow[t]{4}{*}{$\begin{array}{l}\text { Student } \\
\text { learning } \\
\text { activities }\end{array}$} & $\begin{array}{l}\text { 11. Connecting with the } \\
\text { development of science and } \\
\text { technology }\end{array}$ & 4 & 3 & $87,5 \%$ & Very valid \\
\hline & & $\begin{array}{l}\text { 12. Br able to know the weaknesses } \\
\text { and strengths of students }\end{array}$ & 3 & 3 & $75 \%$ & Very valid \\
\hline & & $\begin{array}{l}\text { 13. In accordance with the material } \\
\text { concept presented by the short } \\
\text { story text expert. }\end{array}$ & 3 & 3 & $75 \%$ & Very valid \\
\hline & & $\begin{array}{l}\text { 14. Can increase student } \\
\text { participation in practicum on } \\
\text { learning to analyze elements of } \\
\text { short story text builder. }\end{array}$ & 4 & 4 & $100 \%$ & Very valid \\
\hline \multirow[t]{2}{*}{$\mathrm{D}$} & \multirow[t]{2}{*}{$\begin{array}{l}\text { Supporting } \\
\text { material }\end{array}$} & $\begin{array}{l}\text { 15. Using technological } \\
\text { developments in accordance with } \\
\text { the type of bills given. }\end{array}$ & 4 & 4 & $100 \%$ & Very valid \\
\hline & & $\begin{array}{l}\text { 16. Contains the relevance of the use } \\
\text { of media in the percentage } \\
\text { according to the type of task }\end{array}$ & 4 & 4 & $100 \%$ & Very valid \\
\hline
\end{tabular}




\begin{tabular}{|c|c|c|c|}
\hline Total & 56 & 76 & 132 \\
\hline Validation results & $82,5 \%$ & Very valid \\
\hline
\end{tabular}

Based on the material expert assessment table on the feasibility of peer assessment based scientific attitude assessment instruments, the percentage score was $82.5 \%$. The percentage is obtained from the calculation:

Data analysis

$$
\text { Percentage }=\frac{136}{16} \times 100 \%=82.5 \%
$$

The material expert validation on the development of a scientific attitude assessment instrument based on peer assessment on the competence of analyzing short story texts was carried out by Prof. Dr. Amrin Saragih, M.A., Ph.D., And Dr. Malan Lubis, M.Hum., The information used to assess the quality of learning analyzes short story texts, especially in Basic Competencies: able to analyze the elements of short story builders and the values of life contained in them. Validation results in the form of a score of assessment of the components of learning to analyze short story texts that include: the appropriateness of the instrument, presentation of instruments, and language in the instrument.

The results of the assessment of the subject matter analyzing the short story text developed received several comments and suggestions by material experts that the scientific attitude assessment instrument based on peer assessment learning to analyze the short story text can be tested after a small revision.

Tabel 4.5 Advices of Material Expert

\begin{tabular}{|c|c|}
\hline $\begin{array}{l}\text { Validation } \\
\text { Aspect }\end{array}$ & Advices \\
\hline \multirow[t]{4}{*}{ Material } & 1. Word is replaced by preface \\
\hline & 2. Pay attention to the use of letters (font) \\
\hline & 3. Customize multiple choice material with achievements \\
\hline & $\begin{array}{l}\text { 4. Choose short story texts that encourage students' } \\
\text { curiosity }\end{array}$ \\
\hline
\end{tabular}

\section{a. Analysis of Evaluation Experts}

Tabel 4.6 Results of Validation of Evaluation Experts

\begin{tabular}{|c|c|c|c|c|c|c|}
\hline \multirow[t]{2}{*}{ No. } & \multirow[t]{2}{*}{ Aspect } & \multirow[t]{2}{*}{ Indicator } & \multicolumn{2}{|c|}{$\begin{array}{c}\text { Validato } \\
\mathbf{r}\end{array}$} & \multirow[t]{2}{*}{$\%$} & \multirow{2}{*}{$\begin{array}{l}\text { Criteri } \\
\quad \mathbf{a}\end{array}$} \\
\hline & & & 1 & 2 & & \\
\hline \multirow[t]{3}{*}{$\mathrm{A}$} & \multirow[t]{3}{*}{$\begin{array}{l}\text { Compatibili } \\
\text { ty of } \\
\text { material } \\
\text { with KI and } \\
\text { KD }\end{array}$} & $\begin{array}{l}\text { 1. The material in the } \\
\text { scientific attitude } \\
\text { assessment instrument is } \\
\text { in accordance with KI } \\
\text { and KD }\end{array}$ & 4 & 4 & $100 \%$ & $\begin{array}{l}\text { Very } \\
\text { valid }\end{array}$ \\
\hline & & $\begin{array}{l}\text { 2. Material relevant to } \\
\text { competencies that must } \\
\text { be mastered by students }\end{array}$ & 3 & 3 & $75 \%$ & valid \\
\hline & & $\begin{array}{l}\text { 3. Compatibility of material } \\
\text { with indicators and } \\
\text { learning objectives }\end{array}$ & 3 & 3 & $75 \%$ & valid \\
\hline
\end{tabular}




\begin{tabular}{|c|c|c|c|c|c|c|}
\hline & & $\begin{array}{l}\text { 4. Systematic preparation of } \\
\text { material content }\end{array}$ & 3 & 3 & $75 \%$ & valid \\
\hline \multirow[t]{4}{*}{$\mathrm{B}$} & \multirow{4}{*}{$\begin{array}{l}\text { Language } \\
\text { and } \\
\text { instrument } \\
\text { writing }\end{array}$} & $\begin{array}{l}\text { 1. Using language that is in } \\
\text { accordance with PUEBI and easy } \\
\text { to understand }\end{array}$ & 4 & 4 & $100 \%$ & $\begin{array}{l}\text { Very } \\
\text { valid }\end{array}$ \\
\hline & & $\begin{array}{l}\text { 2. Consistent use of fonts } \\
\text { (letters) }\end{array}$ & 4 & 4 & $100 \%$ & $\begin{array}{l}\text { Very } \\
\text { valid }\end{array}$ \\
\hline & & $\begin{array}{l}\text { 3. Use the right distance, row and } \\
\text { space }\end{array}$ & 3 & 4 & $87,5 \%$ & $\begin{array}{l}\text { Very } \\
\text { valid }\end{array}$ \\
\hline & & $\begin{array}{l}\text { 4. Use paper format and typing } \\
\text { layout }\end{array}$ & 3 & 3 & $75 \%$ & valid \\
\hline \multirow[t]{4}{*}{$\mathrm{C}$} & \multirow{4}{*}{$\begin{array}{l}\text { Student } \\
\text { learning } \\
\text { activities }\end{array}$} & $\begin{array}{l}\text { 1. Connect with the development } \\
\text { of student knowledge }\end{array}$ & 3 & 4 & $87,5 \%$ & $\begin{array}{l}\text { Very } \\
\text { valid }\end{array}$ \\
\hline & & $\begin{array}{l}\text { 2. Can know the weaknesses and } \\
\text { strengths of students }\end{array}$ & 3 & 4 & $87,5 \%$ & $\begin{array}{l}\text { Very } \\
\text { valid }\end{array}$ \\
\hline & & $\begin{array}{l}\text { 3. In accordance with the concept } \\
\text { of short stories to make it easier } \\
\text { for students to understand short } \\
\text { stories }\end{array}$ & 3 & 3 & $75 \%$ & valid \\
\hline & & $\begin{array}{l}\text { 4. Can increase student } \\
\text { participation in assessing short } \\
\text { story learning }\end{array}$ & 3 & 4 & $87,5 \%$ & $\begin{array}{l}\text { Very } \\
\text { valid }\end{array}$ \\
\hline \multirow[t]{4}{*}{$\mathrm{D}$} & \multirow[t]{4}{*}{$\begin{array}{l}\text { Learning's } \\
\text { Materials }\end{array}$} & $\begin{array}{l}\text { 1. Contains the relevance of the } \\
\text { use of the instrument in the } \\
\text { percentage according to the type } \\
\text { of task }\end{array}$ & 4 & 3 & $87,5 \%$ & $\begin{array}{l}\text { Very } \\
\text { valid }\end{array}$ \\
\hline & & 2. Depth and breadth of material & 3 & 4 & $87,5 \%$ & $\begin{array}{l}\text { Very } \\
\text { valid }\end{array}$ \\
\hline & & $\begin{array}{l}\text { 3. Conformity to the title with a } \\
\text { description of the contents of the } \\
\text { material and instruments }\end{array}$ & 4 & 4 & $100 \%$ & $\begin{array}{l}\text { Very } \\
\text { valid }\end{array}$ \\
\hline & & $\begin{array}{l}\text { 4. Systematic preparation of } \\
\text { materials }\end{array}$ & 4 & 4 & $100 \%$ & $\begin{array}{l}\text { Very } \\
\text { valid }\end{array}$ \\
\hline \multirow[t]{2}{*}{$\mathrm{E}$} & \multirow[t]{2}{*}{ Assessment } & 1. Conformity with the material & 3 & 4 & $87,5 \%$ & $\begin{array}{l}\text { Very } \\
\text { valid }\end{array}$ \\
\hline & & 2. Conformity of assessment & 3 & 3 & $75 \%$ & Very \\
\hline
\end{tabular}




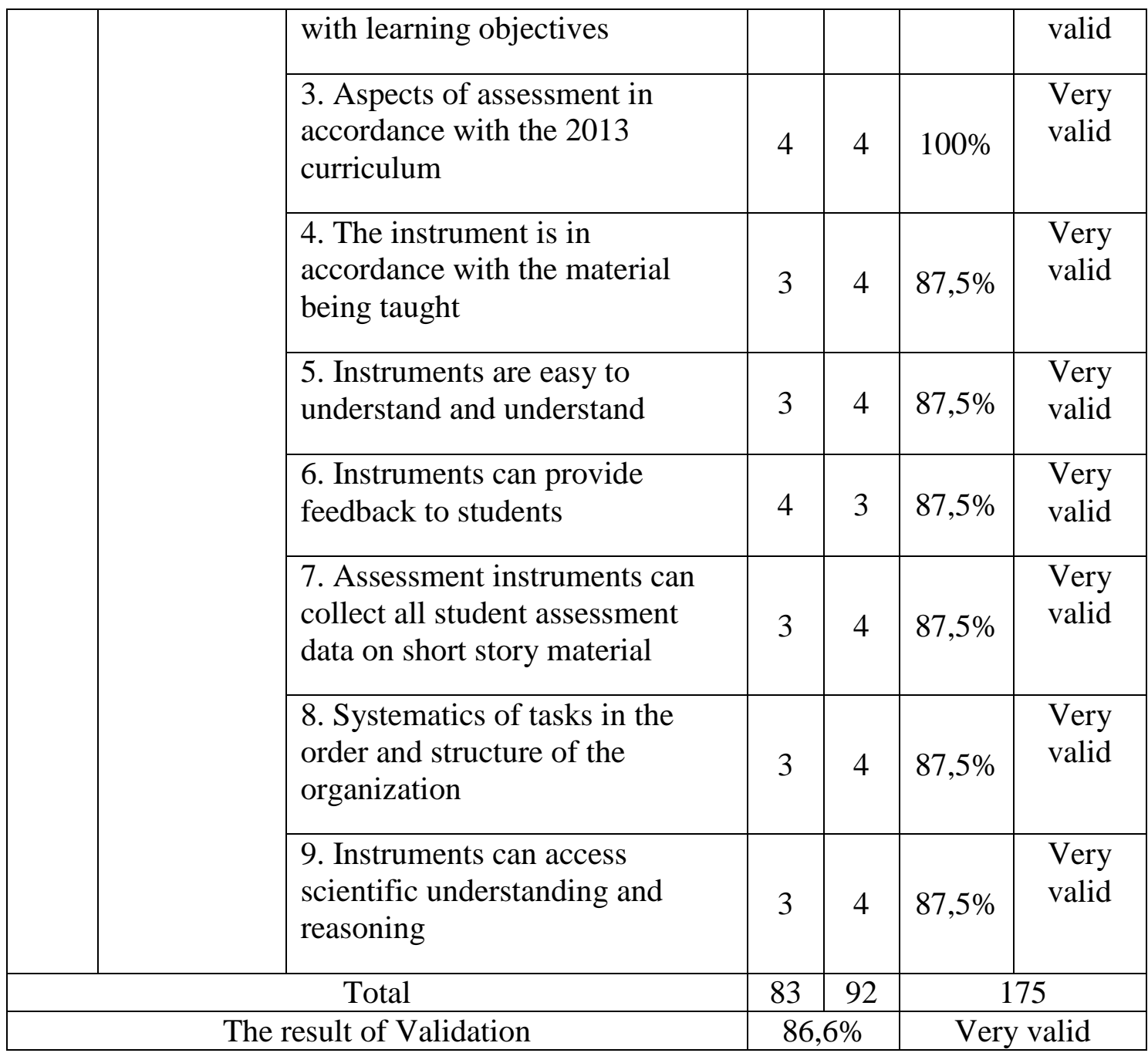

Based on the expert evaluation table of the peer assessment based scientific attitude assessment instrument, a score of $86.6 \%$ was obtained. The percentage is obtained from the calculation:

$$
\text { Percentage }=\frac{175}{23} x 100 \%=86,6 \%
$$

\section{Data analysis}

The expert validation of the evaluation of the development of peer assessment scientific attitude assessment instruments was validated by Prof. Dr. Efendi Napitupulu, M.Pd., and Prof. Dr. Abdul Muin Sibuea, M.Pd .. Information obtained for quality assessment Scientific attitude assessment instruments based on peer assessment in analyzing short story texts that include: the appropriateness of instruments, the presentation of instruments, and language in the instrument.

From the table above, it can be concluded that the evaluation results of the expert stated that the score percentage in the assessment instrument was categorized very well. In addition to giving value, the experts also provided input in the form of comments and suggestions related to the aspects assessed in the scientific attitude assessment instrument based on peer assessment. The following are comments and suggestions given by the evaluation expert. 
Tabel 4.7 The Advices of Material Experts

\begin{tabular}{|l|l|}
\hline $\begin{array}{l}\text { Aspect } \\
\text { validation }\end{array}$ & \multicolumn{1}{c|}{ Advices } \\
\hline Evaluation & 1. The instrument has not been neatly arranged \\
\cline { 2 - 2 } & 2. Pay attention to the writing and use of letters (font) \\
\cline { 2 - 2 } & 3. Pay attention to the question sheet \\
\cline { 2 - 2 } & 4. Clarify how to use the instrument \\
\hline
\end{tabular}

The following is a table of results of the percentage of individual trials.

Tabel 4.8 Percentage of Instrument Feasibility Responses Individual Trial

\begin{tabular}{|c|c|c|c|c|}
\hline No. & Assessment Indicator & Amount & $\begin{array}{c}\text { Percenta } \\
\text { ge }(\%)\end{array}$ & criteria \\
\hline 1. & Material compatibility & 8 & 88,89 & Very Good \\
\hline 2. & Ease of understanding learning & 7 & 77,78 & Good \\
\hline 3. & Adequacy of training & 6 & 66,67 & Enough \\
\hline 4. & Feedback clarity & 8 & 88,89 & Very Good \\
\hline & TOTAL & 25 & 80,56 & Good \\
\hline
\end{tabular}

Tabel 4.9 Percentage of Instrument Clarity Response Individual Trial

\begin{tabular}{|c|l|c|c|l|}
\hline No. & Assessment Indicator & Amount & $\begin{array}{c}\text { Percenta } \\
\text { ge } \mathbf{( \% )}\end{array}$ & Criteria \\
\hline 1. & Clarity of instrument & 9 & 100 & Very Good \\
\hline 2. & Text readability & 8 & 88,89 & Very Good \\
\hline 3. & Clarity of words / sentences & 8 & 88,89 & Very Good \\
\hline \multicolumn{2}{r|}{ TOTAL } & 25 & 92,59 & Very Good \\
\hline
\end{tabular}

From Table 4.8 and Table 4.9, it can be concluded that the results of the assessment and individual responses as a whole can be concluded that the percentage of the average value of the indicator is $86.58 \%$, where the range is $85 \% \leq \mathrm{X} \% 100 \%$, then the assessment tendency individuals are stated as "Very Good".

In the one-on-one trial conducted on 3 students of class XI IPS2 in SMA 1 Kualuh Hilir, Labuhanbatu Utara District, there were inputs and errors that needed to be revised to the product. Suggestions and comments from individual trials and errors can be seen in Table 4.13 below.

The following is a table of results of the percentage of feasibility of group trial instruments.

Tabel 4.10 Instrument Feasibility Percentage Small Group Trial

\begin{tabular}{|c|l|c|c|c|}
\hline No. & Assessment Indicator & Amount & $\begin{array}{c}\text { Percenta } \\
\text { ge }(\boldsymbol{\%})\end{array}$ & Criteria \\
\hline 1. & Material compatibility & 22 & 81,48 & Good \\
\hline 2. & $\begin{array}{l}\text { Ease of understanding } \\
\text { learning }\end{array}$ & 22 & 81,48 & Good \\
\hline
\end{tabular}




\begin{tabular}{|c|l|c|c|c|}
\hline 3. & Adequacy of training & 21 & 77,78 & Good \\
\hline 4. & Feedback clarity & 23 & 85,19 & Very good \\
\hline \multicolumn{2}{|c|}{ Total } & 88 & 81,48 & Good \\
\hline
\end{tabular}

From Table 4.10 above, respondents' answers were obtained for indicators: (a) material suitability of $81.48 \%$ and included in the good category, (b) ease of understanding learning at $81.48 \%$ and included in the good category, (c) adequacy of exercises of $77.78 \%$ and included in the good category, and (d) feedback clarity of $85.19 \%$ and included in the excellent category. Thus the dominant small group respondents gave very good responses to the quality of the peer assessment scientific attitude assessment instrument analyzing the short story text in the aspect of instrument feasibility that is equal to $81.48 \%$ and included in the good category.

Tabel 4.11 Instrument Feasibility Percentage Small Group Trial

\begin{tabular}{|l|l|c|c|l|}
\hline $\begin{array}{l}\text { No } \\
\cdot\end{array}$ & Assessment Indicator & Amount & $\begin{array}{c}\text { Percentage } \\
(\boldsymbol{\%})\end{array}$ & Criteria \\
\hline 1. & Clarity of instrument & 23 & 85,19 & Very Good \\
\hline 2. & Text readability & 24 & 88,89 & Very Good \\
\hline 3. & Clarity of words / sentences & 23 & 85,19 & Very Good \\
\hline \multicolumn{2}{r}{ Total Jumlah } & 70 & 86,42 & Very Good \\
\hline
\end{tabular}

From Table 4.11 above, respondents' answers were obtained for the indicators: (a) the clarity of the instruments was $85.19 \%$ and included in the excellent category, (b) the text readability was $88.89 \%$ and included in the excellent category and (c) clarity word / sentence is $85.19 \%$ and is included in the excellent category. Thus the dominant group respondents gave a very good response to the quality of the scientific attitude assessment instrument based on peer-assessment analyzing the short story text on aspects of instrument clarity which amounted to $86.42 \%$ and included in the excellent category.

The following is a table of the feasibility aspects of a large group trial instrument.

Tabel 4.12 Instrument Feasibility Percentage Large Group Trial

\begin{tabular}{|c|l|c|c|c|}
\hline $\begin{array}{c}\text { No } \\
\cdot\end{array}$ & Assessment Indicator & Amount & $\begin{array}{c}\text { Percenta } \\
\text { ge (\%) }\end{array}$ & Criteria \\
\hline 1. & Material compatibility & 75 & 83,33 & Good \\
\hline 2. & Ease of understanding learning & 80 & 88,89 & Very Good \\
\hline 3. & Adequacy of training & 69 & 76,67 & Good \\
\hline 4. & Feedback clarity & 78 & 86,67 & Very Good \\
\hline \multicolumn{2}{r|}{ Total } & 302 & 83,89 & Good \\
\hline
\end{tabular}

From Table 4.12 above, respondents' answers were obtained for indicators: (a) material suitability of $83.33 \%$ and included in the good category, (b) ease of understanding learning by $88.89 \%$ and included in the excellent category, (c) adequacy of training at $76.67 \%$ and included in the good category, and (d) feedback clarity of $86.67 \%$ and included in the excellent category. Thus the dominant small group respondents gave very good responses to the quality of peer assessment scientific attitude assessment instruments analyzing the short 
story text in the aspect of instrument feasibility that is equal to $83.89 \%$ and included in the good category.

Tabel 4.13 Instrument Feasibility Percentage Large Group Trial

\begin{tabular}{|c|l|c|c|l|}
\hline $\begin{array}{c}\text { No } \\
\cdot\end{array}$ & Assessment Indicator & Amount & $\begin{array}{c}\text { Percenta } \\
\text { ge (\%) }\end{array}$ & Criteria \\
\hline 1. & Clarity of instrument & 78 & 86,67 & Very Good \\
\hline 2. & Text readability & 79 & 87,78 & Very Good \\
\hline 3. & Clarity of words / sentences & 78 & 86,67 & Very Good \\
\hline \multicolumn{2}{c}{ Total } & 235 & 87,04 & Very Good \\
\hline
\end{tabular}

From Table 4.13 above, respondents' answers were obtained for the indicators: (a) the clarity of the instruments was $86.67 \%$ and included in the excellent category, (b) the readability of the text was $87.78 \%$ and included in the excellent category, and (c) clarity word / sentence is $86.67 \%$ and is included in the excellent category. Thus the respondents of the dominant small group gave very good responses to the quality of the scientific attitude assessment instrument based on peer-assessment analyzing the short story text on aspects of instrument clarity which was equal to $87.04 \%$ and included in the excellent category.

Conclusions on the results of assessments and responses from field tests on the appropriateness of the instrument, and the clarity of the instrument indicate that overall the criteria are "Very Good".

\section{Pretest Test Results and Post Test Student Learning}

Based on the research that has been done in SMA 1 Kualuh Hilir, Labuhanbatu Utara District on the ability to analyze short story texts in students by using a peer assessment based scientific attitude assessment instrument on 34 students of Class XI IPS1 SMA 1 Kualuh Hilir High School obtained as the following table.

Tabel 4.14 Results of the ability to assess based on aspects of scientific attitude

\begin{tabular}{|c|l|c|c|}
\hline No & Aspects of Scientific Attitude & $\begin{array}{c}\text { Pretest } \\
\text { Average } \\
\text { Value }\end{array}$ & $\begin{array}{c}\text { Postest } \\
\text { Average } \\
\text { Value }\end{array}$ \\
\hline 1 & Curiosity & 48,2 & 82,4 \\
\hline 2 & Objective attitude & 48,2 & 83,5 \\
\hline 3 & Critical attitude & 48,2 & 82,4 \\
\hline 4 & Open minded attitude & 46,5 & 84,7 \\
\hline 5 & Attitude reaching forward & 48,8 & 84,7 \\
\hline 6 & Category: Less \\
& $\begin{array}{c}\text { Enough } \\
\text { Good }\end{array}$ & $\begin{array}{c}29 \text { org }(85,3 \%) \\
5 \text { org (14,7\%) }\end{array}$ & $\begin{array}{c}4 \text { org (14,7\%) } \\
17 \text { org (50,0\%) } \\
\end{array}$ \\
\hline 7 & Enough good & - & 13 org (38,2\%) \\
\hline
\end{tabular}

The results of the recapitulation ability to assess the scientific attitude of students of class XI IPS1 in analyzing short story texts as the following table. 
Budapest International Research and Critics in Linguistics and Education (BirLE) Journal

Volume 2, No 2, May 2019, Page: 187-203

e-ISSN: 2655-1470 (Online), p-ISSN: 2655-2647 (Print)

www.bircu-journal.com/index.php/birle emails: birle.journal@gmail.com birle.journal.qa@gmail.com

Tabel 4.15 The Results of the Ability to Assess Students' Scientific Attitudes

\begin{tabular}{|c|c|c|}
\hline No & Pretest & Postest \\
\hline 1 & 56,0 & 88,0 \\
\hline 2 & 52,0 & 92,0 \\
\hline 3 & 52,0 & 80,0 \\
\hline 4 & 52,0 & 88,0 \\
\hline 5 & 44,0 & 84,0 \\
\hline 6 & 60,0 & 80,0 \\
\hline 7 & 44,0 & 76,0 \\
\hline 8 & 56,0 & 84,0 \\
\hline 9 & 40,0 & 80,0 \\
\hline 10 & 52,0 & 84,0 \\
\hline 11 & 60,0 & 88,0 \\
\hline 12 & 44,0 & 80,0 \\
\hline 13 & 36,0 & 88,0 \\
\hline 14 & 36,0 & 72,0 \\
\hline 15 & 40,0 & 88,0 \\
\hline 16 & 40,0 & 84,0 \\
\hline 17 & 44,0 & 84,0 \\
\hline 18 & 52,0 & 80,0 \\
\hline 19 & 52,0 & 76,0 \\
\hline 20 & 32,0 & 88,0 \\
\hline 21 & 60,0 & 72,0 \\
\hline 22 & 48,0 & 96,0 \\
\hline 23 & 48,0 & 68,0 \\
\hline 24 & 40,0 & 96,0 \\
\hline 25 & 44,0 & 92,0 \\
\hline 26 & 48,0 & 84,0 \\
\hline 27 & 44,0 & 76,0 \\
\hline 28 & 52,0 & 92,0 \\
\hline 29 & 44,0 & 84,0 \\
\hline 30 & 60,0 & 80,0 \\
\hline 31 & 60,0 & 88,0 \\
\hline 32 & 52,0 & 68,0 \\
\hline 33 & 44,0 & 84,0 \\
\hline 34 & 44,0 & 96,0 \\
\hline Average & 48,0 & 83,5 \\
\hline
\end{tabular}

Based on Table 4.15 above, it can be concluded that the average ability to judge scientifically at pretest is 48.0. The pretest results fall into the less category. In the posttest obtained the average ability to assess scientifically is 83.5 . Posttest results are included in the good category. 
To see the value of the percentage of responses given by students of class XI IPS1 SMA Negeri 1 Kualuh Hilir towards the use of peer assessment assessments based on scientific attitude assessment instruments used the formula:

$$
\mathrm{R}=\frac{\mathrm{x}}{\mathrm{N}} \times 100
$$

From the previous data obtained:

$$
\begin{aligned}
\mathrm{x} & =4,2 \\
\mathrm{~N} & =5
\end{aligned}
$$

So:

$$
\begin{aligned}
\mathrm{R} & =\frac{4,2}{5} \times 100 \\
& =83,2 \%
\end{aligned}
$$

The value of $\mathrm{R}$ is consulted with the provisions stated by Hobri, which results in an $\mathrm{R}=$ 83.2 which is above $80 \%$. Thus the instrument of the peer assessment based on scientific attitude assessment instrument that can be said to be practical.

Furthermore, to see the effectiveness of the use of peer assessment based scientific attitude assessment instruments, the t-test was used. Calculations using the t-test:

$$
\mathrm{t}=\frac{\overline{\mathrm{X}}-\mu_{\mathrm{O}}}{\mathrm{s} / \sqrt{\mathrm{n}}}
$$

From the previous data obtained:

$$
\begin{aligned}
\bar{X} & =83,5 \text { (Average posttest) } \\
\mu_{O} & =48,0 \text { (Average pretest) } \\
\mathrm{s} & =7,4 \text { (standard deviasion posttest) } \\
\mathrm{n} & =34 \text { (sampel) }
\end{aligned}
$$

So:

$$
\begin{aligned}
t & =\frac{83,5-48,0}{7,4 \sqrt{34}} \\
& =\frac{35,5}{7,4 \times 5,83} \\
& =0,822
\end{aligned}
$$

From the distribution table for $\alpha=0.05$ and $\mathrm{dk}=34$, the value of t-criticism was obtained with a significance of $5 \%$ of 2.042 . Thus the value of $t_{\text {count }}$ is at the reception area, namely: $-2,042<0,822<2,042$; which concluded that there was a difference in the ability to assess the scientific before treatment with after treatment using a peer assessment based scientific attitude assessment instrument in students of SMA 1 Kualuh Hilir High School Labuhanbatu Utara Learning Year 2018/2019.

\section{Conclusion}

Based on the results and discussion of the study it can be concluded that the peer assessment based scientific attitude assessment instrument can be used as a short story text learning instrument for class XI IPS in SMA 1 Kualuh Hilir, North Labuhanbatu Regency. This can be seen from the increase in the value of the ability to assess at the pretest (48.0) and posttest (83.5). 
The results of the assessment showed that the overall assessment instrument based on peer assessment was feasible to use with a practicality value of $83.5 \%$. This shows that the scientific attitude assessment instrument based on peer assessment compiled by practical researchers can be used in learning to analyze short story texts.

The peer assessment based scientific attitude assessment instrument used has also been tested on students to see the ability to assess short story texts of students of class XI IPS in SMA 1 Kualuh Hilir, Labuhanbatu Utara Regency. These results are based on the value of tcount obtained 0.822 and are in the critical acceptance area at a significance level of $5 \%$, namely: $-2.042<0.822<2.042$. This concludes that there is a significant difference in the ability to judge scientifically before treatment with after treatment using a peer assessment based scientific attitude assessment instrument for class XI students of SMA 1 Kualuh Hilir SMA Labuhanbatu Utara Learning Year 2018/2019.

\section{References}

Anshari, et al. 2014. Pengembangan Model Penilaian Peer-Self Assessment

Termoderasi Guru Berbasis Web untuk Pelajaran Fisika SMA. Vol. 3 no. 1.http://jurnalonline.um.ac.id/article/do/detail-article/1/35/1935 (Accessed on April 25th, 2018).

Anwar, Herson. 2009. Penilaian Sikap Ilmiah dalam Pembelajaran Sains. http:/ejurnal.ung.ac.id (Accessed on Juny 25th, 2018)

Arikunto, Suharsimi. 2013. Prosedur Penelitian Suatu Pendekatan Praktik. Jakarta: Rineka Cipta

Basri, Qabliah. (2017). Pengembangan Penilaian Kinerja Teknik Peer Assessment pada Pembelajaran Biologi. Thesis published. Makassar: Prodi Pendidikan Biologi UIN Alauddin Makassar.

Bustan. 2010. Perangkat Pembelajaran Matematika Berbahasa Inggris berbasis Realistik pada SMP Rintisan Sekolah Bertarap Internasional. Thesis. Universitas Negeri Makassar.

Dewan Perwakilan Rakyat RI dan Presiden RI. 2003. Undang-undang Sistem Pendidikan Nasional: SISDIKNAS

Hosnan. 2014. Pendekatan Saintifik dan Kontekstual dalam Pembelajaran Abad 21: Kunci Sukses Implementasi Kurikulum 2013. Jakarta: Ghalia Indonesia

Kosasih, E. (2012). Dasar-dasar Keterampilan Bersastra. Bandung: Yrama Widya.

Kunandar. 2013. Penilaian Autentik: Penilaian Hasil Belajar Peserta Didik Berdasarkan Kurikulum 2013. Jakarta: PT raja Grafindo Persada

Lestari, et al. 2016. Analisis Unsur Intrinsik Dan Ekstrinsik Pada Kumpulan Cerpen Pilihan Kompas 2014 Serta Relevansinya Sebagai Materi Pembelajaran Sastra Di Sekolah Menengah Atas. Universitas Sebelas Maret. Vol 4, ISSN 12302-6405. Print (accessed on May 11th, 2018)

Lestari, Puji. 2014. Sikap Ilmiah Siswa Kelas XI IPA 1 SMA N 3 Bengkulu Tengah pada Pembelajaran Biologi Berpendekatan Inkuiri. Thesis. Universitas Bengkulu

Lestari. 2017. Pengembangan Instrumen Penilaian Praktikum pada Materi StrukturJaringan pada tumbuhan Siswa Kelas XI SMA N 16 Makassar. Thesis. UIN Alauddin Makassar.

Nurgiyantoro, Burhan. 2011. Penilaian Otentik dalam Pembelajaran Bahasa. Yogyakarta: gajah mada University Press

Nurhardini, Rachmi. 2017. Pengaruh Self dan Peer Assessment pada Materi ekosistem Terhadap Berpikir Aplikatif dan kritis Siswa SMA. SMAN 3 
Ternate. Vol. 1 e-ISSN: 2594-1458. (Accessed on April 29th, 2018)

Purwanto. 2012. Instrumen Penelitian Sosial dan pendidikan. Yogyakarta: Pustaka Pelajar

Ratna, N.K.S.U. (2014). Peranan Karya Sastra, Seni, dan Budaya dalam Pendidikan Karakter.Yogyakarta: PustakaPelajar.

Rani, et al. 2010. Penerapan Peer Assessment dalam Menilai Sikap Ilmiah Soswa pada Mata Pelajaran Fisika SMA Kelas X. Universitas Negeri Semarang. ISBN 987-602-97835-06. Print. (Accessed on July 31st, 2018)

Rokhmansyah.A., (2014).Studidan Pengkajian Sastra: Perkenalan Awal Terhadap Ilmu Sastra.Yogyakarta: Grahallmu.

Siagian, Daut. 2014. Pengembangan Instrumen dan Bahan Ajar berbasis Pendekatan Pembelajaran SAVI untuk Meningkatkan Kemampuan Koneksi Matematis Siswa SMP Kelas VIII. Thesis. Universitas Negeri Medan: Prodi Pendidikan Matematika

Sriyanti, et al 2013. Kemampuan Menulis Resensi Cerpen Siswa Kelas Xi SMA Negeri 1 Bengkunat Lampung Barat. Universitas Lampung. Jurnal Kata. Print (Accessed on May 21st, 2018)

Subali, Muhammad. 2014. Perangkat Pembelajaran Matematika berbasis SMART. Universitas Gunung Jati. Vol.3 No.1. Print (Accessed on Juli 21st, 2018)

Sudjana, Nana. 2009. Penilain Hasil Proses Belajar Mengajar, Bandung: Remaja Rosdakarya

Sufanti, et al. 2018. Pemilihan Cerita Pendek Sebagai Materi Ajar Pembelajaran Sastra Oleh Guru Mata Pelajaran Bahasa Indonesia Sma Di Surakarta. Universitas Negeri Semarang. Vol, 19. No.1. Print ( accessed may 11st, 2018)

Sugiyono. 2012. Metode Penelitian Pendidikan Pendekatan Kuantitatif, kualitatif

dan R\&D. Bandung: Alfabeta

Sunarti dan Selly. 2014. Penilaian kurikulum 2013: Membantu Guru dan Calon Guru Mengetahui langkah-langkah Penilaian Pembelajaran. Yogyakarta:Andi

Suryani, Iis. 2016. Pengembangan Instrumen Penilaian Sikap Ilmiah pada Pembelajaran dengan Model Latihan Penelitian di Sekolah Dasar. Universitas Pendidikan Indonesia. Print ( Accessed on April 27th, 2018)

Tian, et al. 2016. Pembelajaran Menyunting Teks Cerita Pendek Berdasarkan Kurikulum 2013 di Kelas XI IB 2 SMA Negeri 1 Blahbatuh. Universitas Pendidikan Ganesha. Vol 5, No:3. Print (Accessed on May 11st, 2018) 